\title{
HUBUNGAN PENGETAHUAN KEBERSIHAN GIGI DAN MULUT DENGAN STATUS KEBERSIHAN GIGI DAN MULUT PADA SISWA SMA NEGERI 9 MANADO
}

\author{
${ }^{1}$ Yohanes I Gede K.K. \\ ${ }^{2}$ Karel Pandelaki \\ ${ }^{3} \mathrm{Ni}$ Wayan Mariati \\ ${ }^{1}$ Kandidat skripsi Program Studi Kedokteran Gigi Fakultas Kedokteran \\ Universitas Sam Ratulangi Manado \\ ${ }^{2}$ Bagian Kedokteran Umum Fakultas Kedokteran \\ Universitas Sam Ratulangi Manado \\ ${ }^{3}$ Bagian Kedokteran Gigi Program Studi Kedokteran Gigi Fakultas Kedokteran \\ Universitas Sam Ratulangi Manado \\ Email: yosh_kun.kurosagi@yahoo.com
}

\begin{abstract}
Abstrak: Pengetahuan tentang kebersihan gigi dan mulut sangat penting untuk terbentuknya tindakan dalam menjaga kebersihan gigi dan mulut. Kebersihan gigi dan mulut dilakukan untuk mencegah penyakit gigi dan mulut, meningkatkan daya tahan tubuh, dan memperbaiki fungsi mulut untuk meningkatkan nafsu makan. Menjaga kebersihan gigi dan mulut pada usia sekolah merupakan salah satu cara dalam meningkatkan kesehatan pada usia dini. Hasil penelitian ini menunjukkan bahwa tingkat pengetahuan kebersihan gigi dan mulut siswa SMA Negeri 9 Manado sudah cukup baik yang mencapai hasil 95,00\%. Status kebersihan gigi dan mulut siswa SMA Negeri 9 Manado dilihat melalui pemeriksaan OHI-S dengan siswa yang memiliki OHI-S baik (48,75\%), OHI-S sedang (51,25\%) dan tidak ada yang memiliki OHI-S yang buruk.
\end{abstract}

Kata kunci: pengetahuan, kebersihan gigi dan mulut, usia sekolah.

\begin{abstract}
Knowledge about oral hygiene is essential for the formation of action in maintaining oral hygiene. Oral hygiene to prevent gum disease, increase endurance, and improve the function of the mouth to enhance appetite. Maintain oral hygiene at school age is one way to improve health at an early age. Results of this study indicate that the level of knowledge of oral hygiene 9 Manado State high school students has been good enough to reach the result $95.00 \%$. Dental and oral hygiene status of students of SMA Negeri 9 Manado seen through examination OHI-S with the majority of students have a good OHI-S (48.75\%) and moderate (51.25\%) and no one has a bad OHI-S.
\end{abstract}

Key words: knowledge, oral hygiene, school age.

Pemeliharaan kesehatan gigi dan mulut merupakan salah satu upaya meningkatkan kesehatan. Salah satu penyebab seseorang mengabaikan masalah kesehatan gigi dan mulutnya adalah faktor pengetahuan tentang kebersihan gigi dan mulut yang kurang. Masalah kesehatan gigi dan mulut seperti karies, gingivitis, radang dan stomatitis pada kelompok usia sekolah menjadi perhatian yang penting dalam pembangunan kesehatan yang salah satunya disebabkan oleh rentannya kelompok usia sekolah dari gangguan kesehatan gigi dan mulut. Hal itu dilandasi oleh kurangnya pengetahuan dan kesadaran akan pentingnya pemeliharaan gigi dan mulut.

World Health Organisation (WHO) dalam The World Oral Health Report 
menyatakan bahwa di Indonesia kurangnya menjaga kebersihan gigi dan mulut berakibat pada meningkatnya prevalesi edentulousness yang mencapai $24 \%$ dengan rata-rata umur di atas 65 tahun dan penduduk Indonesia yang menderita gangguan kesehatan gigi dan mulut masih mencapai 90\% . ${ }^{1,2}$ Penelitian Denloye di Nigeria pada anak berumur 13-15 tahun yang dituangkan dalam jurnalnya membuktikan bahwa besar Debris Indeks (DI) mencapai 1,57 dan besar Kalculus Indeks (CI) mencapai 1,48 dengan rata-rata Oral Hygiene Index Status (OHI-S) untuk lakilaki mencapai 3,09 dan untuk perempuan mencapai 2,94 yang tergolong ringan sampai sedang. ${ }^{3}$ Hasil-hasil penelitian ini menunjukkan bahwa kurangnya kesadaran diri masyarakat terutama pada anak usia sekolah untuk menjaga kesehatan gigi dan mulutnya sehingga perlu dilakukan penelitian lebih lanjut untuk mengetahui hubungan pengetahuan tentang kebersihan gigi dan mulut dengan status kebersihan gigi dan mulut pada siswa usia sekolah terutama pada siswa sekolah menengah atas mengingat bahwa pada usia tersebut sebagian besar gigi permanennya sudah tumbuh sempurna.

Pengetahuan anak SMA sendiri tentang kebersihan gigi dan mulut sendiri sebenarnya bisa didapat dari berbagai sumber meskipun belum ada penelitian pasti tentang hal itu. Pengetahuan itu bisa berasal dari media online, internet yang semakin canggih, apalagi kalau kita perhatikan internet merupakan bagian dari kehidupan anak-anak SMA saat ini. Peneliti sendiri tertarik untuk melakukan penelitian ini karena merasa perlu untuk mengetahui sejauh mana hubungan pengetahuan pernah dilakukan di sekolah tersebut. Peneliti telah melakukan kunjungan pendahuluan pada beberapa kesempatan sebelumnya sehingga peneliti tertarik untuk melakukan penelitian tersebut.

\section{BAHAN DAN METODE}

Penelitian ini bersifat deskriptif analitik dengan pendekatan cross sectional. Penelitian ini telah dilaksanakan dari tanggal 1 April 2013 sampai 12 April 2013 sesuai dengan izin pihak sekolah. Lokasi penelitian berada di ruangan kelas SMA Negeri 9 Manado. Keseluruhan sampel pada penelitian ini adalah siswa-siswi SMA Negeri 9 Manado khususnya kelas Binsus (Binaan Khusus) sebanyak 267 siswa dengan sampel adalah siswa kelas X dan XI di SMA Negeri 9 Manado yang berumur 14 sampai 17 tahun yang berjumlah 160 siswa dengan menggunakan rumus tertentu. Teknik pengumpulan data yang digunakan dalam penelitian ini dengan menggunakan kuesioner dan pemeriksaan OHI-S pada sampel. Pada penelitian ini, variabel yang digunakan adalah pengetahuan kebersihan gigi dan mulut yang dibagi ke dalam 3 kategori yaitu: nilai baik (14-19 benar), sedang (7-13 benar) dan buruk (0-6 benar) yang akan diukur dengan menggunakan kuesioner dan pemeriksaan kebersihan gigi dan mulut yang juga dibagi ke dalam 3 kategori menggunakan indeks Green and Vermillion yaitu: nilai baik (0$1,2)$, sedang $(1,3-3,0)$ dan buruk $(3,1-6,0)$ yang akan diukur dengan pemeriksaan OHIS. Data diolah dan disajikan dalam bentuk tabel distribusi siswa kemudian dianalisis secara deskriptif analitik berdasarkan hasil persentase.

\section{HASIL PENELITIAN}

Dari keseluruhan siswa kelas X dan XI sebanyak 267 siswa, yang diteliti sebanyak 160 siswa terdiri dari siswa laki-laki dan perempuan dengan jumlah masing-masing 80 siswa, dengan usia 14 sampai 17 tahun. Dari seluruh siswa yang diteliti ditemukan sebanyak 74 siswa yang memiliki pengetahuan baik tentang kebersihan gigi dan mulut dengan hasil pemeriksaan OHI-S baik (46,25\%). Sebanyak 78 siswa yang memiliki pengetahuan baik tentang kebersihan gigi dan mulut dengan hasil pemeriksaan OHI-S sedang (48,75\%). Sebanyak 4 siswa yang memiliki pengetahuan sedang tentang kebersihan gigi dan mulut dengan hasil pemeriksaan OHI-S baik (2,50\%). Sebanyak 4 siswa yang memiliki pengetahuan sedang tentang kebersihan gigi dan mulut yang menunjukkan hasil pemeriksaan OHIS sedang (2,50\%). Tidak ada siswa yang 
memiliki pengetahuan buruk maupun OHI-S buruk. Hasil analisis statistik menunjukkan bahwa nilai $\mathrm{p}$ value $=0,079$, maka dapat disimpulkan bahwa terdapat hubungan antara pengetahuan kebersihan gigi dan mulut dengan status kebersihan gigi dan mulut ( $\mathrm{p}$ value: $0,079, \alpha: 0,10$ ). Hasil analisis juga diperoleh nilai $\mathrm{OR}=2,2$, artinya siswa yang memiliki pengetahuan yang baik memiliki peluang 2,2 kali untuk memiliki status kebersihan gigi dan mulut yang baik. Keterangan selengkapnya dapat dilihat pada tabel 1 .

Tabel 1. Distribusi keseluruhan siswa berdasarkan hubungan pengetahuan kebersihan gigi dan mulut dengan status kebersihan gigi dan mulut

\begin{tabular}{ccccc}
\hline \multirow{2}{*}{ Pengetahuan } & \multicolumn{3}{c}{ OHI-S } & \multirow{2}{*}{ Total } \\
\cline { 2 - 4 } & Baik & Sedang & Buruk & \\
\hline Baik & 74 & 78 & 0 & 152 \\
Sedang & 4 & 4 & 0 & 8 \\
Buruk & 0 & 0 & 0 & 0 \\
Total & 78 & 82 & 0 & 160 \\
\hline (*P value $=0,079 ;$ OR $=2,2)$ & &
\end{tabular}

Hasil penelitian ini dikategorikan juga berdasarkan jenis kelamin yaitu siswa lakilaki dan perempuan dengan jumlah masingmasing 80 siswa. Dari siswa laki-laki ditemukan sebanyak 28 siswa yang memiliki pengetahuan baik tentang kebersihan gigi dan mulut dengan hasil pemeriksaan OHI-S baik (35,00\%). Sebanyak 45 siswa yang memiliki pengetahuan baik tentang kebersihan gigi dan mulut dengan hasil pemeriksaan OHI-S sedang (60,00\%). Sebanyak 3 siswa yang memiliki pengetahuan sedang tentang kebersihan gigi dan mulut dengan hasil pemeriksaan OHI-S baik (3,75\%). Sebanyak 4 siswa yang memiliki pengetahuan sedang tentang kebersihan gigi dan mulut yang menunjukkan hasil pemeriksaan OHI-S sedang (5,00\%). Tidak ada siswa yang memiliki pengetahuan buruk maupun OHI-S buruk. Namun dari hasil analisis statistik diperoleh nilai $\mathrm{p}$ value $=0,113$, sehingga dapat disimpulkan bahwa hubungan antara pengetahuan kebersihan gigi dan mulut dengan status kebersihan gigi dan mulut tidak signifikan ( $\mathrm{p}$ value: $0,113, \alpha$ : 0,10). Hasil analisis juga diperoleh nilai $\mathrm{OR}=0,8$, artinya siswa laki-laki yang memiliki pengetahuan yang baik memiliki peluang 0,8 kali untuk memiliki status kebersihan gigi dan mulut yang baik. Keterangan selengkapnya dapat dilihat pada tabel 2.

Tabel 2. Distribusi siswa berdasarkan hubungan pengetahuan kebersihan gigi dan mulut dengan status kebersihan gigi dan mulut pada siswa laki-laki

\begin{tabular}{ccccc}
\hline \multirow{2}{*}{ Pengetahuan } & \multicolumn{3}{c}{ OHI-S } & \multirow{2}{*}{ Total } \\
\cline { 2 - 4 } & Baik & Sedang & Buruk & \\
\hline Baik & 28 & 45 & 0 & 73 \\
Sedang & 3 & 4 & 0 & 7 \\
Buruk & 0 & 0 & 0 & 0 \\
Total & 31 & 49 & 0 & 80 \\
\hline (*P value $=0,113 ;$ OR $=0,8)$ & &
\end{tabular}

Hal ini berbanding terbalik dengan siswa perempuan yang diteliti. Dari siswa perempuan ditemukan sebanyak 46 siswa yang memiliki pengetahuan baik tentang kebersihan gigi dan mulut dengan hasil pemeriksaan OHI-S baik (35,00\%). Sebanyak 33 siswa yang memiliki pengetahuan baik tentang kebersihan gigi dan mulut dengan hasil pemeriksaan OHI-S sedang (60,00\%). Sebanyak 1 siswa yang memiliki pengetahuan sedang tentang kebersihan gigi dan mulut dengan hasil pemeriksaan OHI-S baik (3,75\%). Tidak ada siswa yang memiliki pengetahuan sedang dengan OHI$\mathrm{S}$ buruk dan tidak ada siswa yang memiliki pengetahuan buruk maupun OHI-S buruk. Hasil analisis statistik diperoleh nilai p value =0,048, maka dapat disimpulkan bahwa terdapat hubungan antara pengetahuan kebersihan gigi dan mulut dengan status kebersihan gigi dan mulut (p value: 0,048, $\alpha: 0,10)$. Hasil analisis juga diperoleh nilai $\mathrm{OR}=1,4$, artinya siswa perempuan yang memiliki pengetahuan yang baik memiliki peluang 1,4 kali untuk memiliki status kebersihan gigi dan mulut yang baik. Keterangan selengkapnya dapat dilihat pada Tabel 3. 
Tabel 3. Distribusi siswa berdasarkan hubungan pengetahuan kebersihan gigi dan mulut dengan status kebersihan gigi dan mulut pada siswa perempuan

\begin{tabular}{ccccc}
\hline \multirow{2}{*}{ Pengetahuan } & \multicolumn{3}{c}{ OHI-S } & \multirow{2}{*}{ Total } \\
\cline { 2 - 4 } & Baik & Sedang & Buruk & \\
\hline Baik & 46 & 33 & 0 & 79 \\
Sedang & 1 & 0 & 0 & 1 \\
Buruk & 0 & 0 & 0 & 0 \\
Total & 47 & 33 & 0 & 80 \\
\hline
\end{tabular}

$(* \mathrm{P}$ value $=0,048 ; \mathrm{OR}=1,4)$

\section{BAHASAN}

Secara keseluruhan hasil penelitian ini menunjukkan adanya hubungan antara pengetahuan dengan kebersihan gigi dan mulut. Ditunjukkan dengan hasil yang menunjukkan sebagian besar siswa sudah memiliki pengetahuan yang baik dengan OHI-S yang baik pula. Laporan hasil penelitian Putu Sri Utari pada 176 siswa sekolah di Cilandak timur menunjukkan bahwa 69 responden (32,2\%) memiliki tingkat pengetahuan rendah sedangkan 107 responden (60,8\%) memiliki tingkat pengetahuan tinggi. Silvia Anitasari juga melakukan penelitian tentang tingkat kebersihan mulut dengan menggunakan indeks OHI-S pada 1650 siswa sekolah di Samarinda mendapatkan 6,73\% siswa keadaan kebersihan gigi dan mulutnya baik; 59,03\% sedang; 34,24\% buruk dengan OHI$\mathrm{S}$ rata-rata adalah 3 termasuk kebersihan gigi dan mulut sedang.Terdapat perbedaan antara hasil penelitian ini dibandingkan dengan penelitian yang dilakukan oleh Denloye di Nigeria pada anak berumur 1315 tahun (siswa SMP), penelitian yang dilakukan oleh Denloye menemukan OHI-S untuk anak pada usia SMP yang tergolong baik sampai sedang. Hal ini kemungkinan karena anak pada usia SMA sudah memiliki pengetahuan yang luas tentang kebersihan gigi dan mulut sehingga mereka mengetahui cara untuk menjaga kebersihan gigi dan mulutnya dengan baik pula.

Berdasarkan hasil penelitian ini diperoleh juga siswa berjenis kelamin perempuan lebih memperhatikan kebersihan gigi dan mulutnya dibandingkan dengan siswa berjenis kelamin laki-laki. Hal ini kemungkinan dapat disebabkan karena pada siswa perempuan memiliki kecenderungan untuk lebih menjaga penampilannya termasuk kebersihan gigi dan mulutnya sedangkan pada sebagian siswa laki-laki yang diteliti rata-rata memiliki kebiasaan merokok yang sudah jelas akan berpengaruh pada derajat kebersihan gigi dan mulut, meskipun sebenarnya mereka sadar bahwa kebiasaan merokok itu tidak baik. Kebiasaan seperti ini jelas harus mendapatkan perhatian dari pihak sekolah untuk memberikan penyuluhan lebih lanjut lagi tentang bahaya merokok bagi kesehatan tubuh pada umumnya dan kebersihan gigi dan mulut pada khususnya mengingat bahwa pada usia mereka saat ini mereka sudah memiliki gigigigi permanen yang perlu dijaga supaya tidak sampai rusak. Kebiasaan yang tidak baik dalam menjaga kebersihan gigi dan mulut dapat berakibat pada munculnya berbagai penyakit sistemik seperti karies, gingivitis, radang, stomatitis dan juga dapat berakibat pada kerusakan pada jaringan periondal gigi. Penyebab lainnya yang ditemukan bahwa mereka banyak mengkonsumsi makanan yang manis-manis di sekolah dan kurang sekali dari mereka yang sadar bahwa pentingnya menyikat gigi sesudah makan dan sebelum tidur malam. Sebab makanan yang tersangkut di gigi akan menjadi tempat bagi bakteri-bakteri yang menjadi penyebab kerusakan gigi. Penyebab lainnya ditemukan hanya sebagian kecil dari mereka yang sadar bahwa perlu pemeriksaan secara rutin ke dokter gigi setiap 6 sekali untuk memeriksakan kesehatan gigi dan mulutnya sebab perawatan gigi merupakan salah satu usaha untuk menjaga dan mencegah kerusakan gigi dan penyakit gusi. Penyebab lainnya lagi ditemukan masih ada siswa yang masih salah dalam cara menggosok gigi. Kesalahan dalam cara menyikat gigi dapat mengakibatkan terkikisnya jaringan pada gusi (resesi gingiva) yang merupakan tempat melekatnya gigi sehingga akan berakibat pada timbulnya rasa nyeri pada gigi (ngilu) pada saat makan atau minum minuman yang terlalu panas atau terlalu dingin. Sekali lagi peran dari 
88 Jurnal e-GiGi (eG), Volume 1, Nomor 2, September 2013, hlm. 84-88

sekolah diperlukan untuk memberikan penyuluhan sehingga mereka dapat lebih menyadari lagi untuk menjaga kebersihan gigi dan mulutnya.

\section{SIMPULAN}

Tingkat pengetahuan kebersihan gigi dan mulut siswa SMA Negeri 9 Manado sudah baik yang mencapai hasil 95,00\%. Status kebersihan gigi dan mulut siswa SMA Negeri 9 Manado dilihat melalui pemeriksaan OHI-S dengan sebagian besar siswa memiliki OHI-S yang baik dan tidak ada yang memiliki OHI-S yang buruk. Siswa perempuan memiliki kecenderungan untuk menjaga kebersihan gigi dan mulutnya dibandingkan dengan siswa lakilaki. Hubungan antara pengetahuan kebersihan gigi dan mulut dengan status kebersihan gigi dan mulut pada siswa SMA Negeri 9 Manado menunjukkan anak yang memiliki pengetahuan yang baik memiliki peluang 2,2 kali untuk memiliki status kebersihan gigi dan mulut yang baik.

\section{SARAN}

Perlu dilakukan penelitian lebih lanjut dengan sampel yang lebih banyak agar lebih menggambarkan populasi yang diteliti. Perlu dilakukan penelitian yang sama terhadap siswa di SMA Negeri 9 Manado namun dengan variabel yang lain seperti perilaku, cara menggosok gigi, latar belakang pendidikan orang tua, dan kebiasaan yang memungkinkan siswa untuk menjaga atau mengabaikan kebersihan gigi dan mulut mereka. Perlu dilakukan penyuluhan mengenai kesehatan gigi-mulut dan cara merawat gigi-mulut secara pribadi pada siswa di SMA Negeri 9 Manado untuk menambah pengetahuan siswa dan dapat menumbuhkan kesadaran mereka untuk selalu menjaga kebersihan gigi dan mulutnya.

\section{DAFTAR PUSTAKA}

1. Poul PE. The World Oral Health Report Continuous Improvement of Oral Health in The 21st Century (Second Edition). Genewa, Switzerland: 20 Avenue Appia, 2003; p.3-5.

2. Denloye. Oral hygiene status of mentally handicapped school childrenin ibadan. Odonto-Stomatologie Tropicale. 2010;86: 20-21.

3. Putu SU. Hubungan tingkat pengetahuan anak tentang kesehatan gigi dan mulut dengan perilaku menggosok gigi pada siswa kelas IV dan kelas V di SDN 01 pagi cilandak timur. Laporan Hasil Penelitian. 2009; 24: 4-5.

4. Silvia A. Hubungan frekuensi menyikat gigi dengan tingkat kebersihan gigi dan mulut siswa sekolah dasar negeri di kecamatan palaran kotamadya samarinda provinsi kalimantan timur. Dent J. 2005;38:88-90.

5. Amsal B. Filsafat ilmu (Edisi Revisi). Jakarta: PT Raja Grafindo Persada, 2004; p. 85-122.

6. Soetriono, Hanafie Rita. Filsafat ilmu dan metodologi penelitian. Yogyakarta: CV Andi Offset, 2007; p. 7-62, 122, 140-3.

7. Ireland R. Clinical Textbook of Dental Hygiene and Therapy. Singapore: Blackwell Munksgaard, 2006; p. 99-138. 